\title{
A Few Good Knowledge Transfer Mechanisms: Keys to Successful Military Operations
}

\author{
Dr. Sheikh Shamim Hasnain \\ University of Bedfordshire, UK
}

\begin{abstract}
This paper aims to conceptualise the knowledge management mechanisms used in the military organisations during the peace and war times. Knowledge management could achieve a vital position in the disciple of Management. Its waves could touch the shores of military forces now. Military units and formations could realise the significance of knowledge management. Knowledge transfer is an indispensable element of knowledge management process. The successful transfer of knowledge ensures victory in the battle, while successful knowledge transfer demands selection and utilisation of appropriate knowledge transfer mechanisms. The paper analyzes and discusses the roles and importance of a few knowledge transfer mechanisms as the vehicles/medias of knowledge transfer in the military forces during peace and war times. The exhibited knowledge transfer mechanisms show how military forces use various techniques and mechanisms to transfer knowledge between the commanders at different levels and the soldiers, and vice versa. These could be further explored during empirical investigations in the military context. The paper will help the business organisations to borrow the military knowledge transfer mechanisms. The transfer mechanisms used in military forces presented here provide a deeper understanding of characteristics and nature of the mechanisms; many of them are different and unique from those of the corporate /business world. The paper is of value to business organisations because it develops a view of new knowledge transfer mechanisms. Further, previous literature fails to address the knowledge transfer mechanisms in the military context, thus this paper reinforces the theories on knowledge transfer mechanisms.
\end{abstract}

Key Words: Knowledge Management, Knowledge Transfer Mechanisms, Military Organisations

\section{INTRODUCTION}

Knowledge Management could achieve huge attention by the academic, corporate and military worlds. After 1995, its popularity has significantly enhanced (Edvardsson, 2006). It has occupied a popular position in the dictionary of Management (Nan, 2008). It has become a crucial strategic tool ((Hasnain, 2016; Debowski, 2006) for the military organisations as well. "Justified True Believe in Context" is identified as knowledge by Gettier (1963). Researchers (Blackler, 1995; Hasnain, 2012) have classified knowledge in different ways. Nonaka and Takeuchi (1995) classified knowledge as tacit and explicit. Tacit knowledge resides inside the human brains and when it is articulated, it becomes explicit knowledge. "How to fire a Semiautomatic Gun?" or "How to drive a car?" are the techniques known by the firers and the drivers respectively? These are the tacit knowledge residing inside the brains of the firers and the drivers. When they present these knowledge in any forms (words, written documents, sound, verbal or any other forms) the knowledge turns into explicit forms. It is imperative for the military and business organisations to manage and transfer this invaluable asset. 
Knowledge acquisition, knowledge storage, knowledge transfer and utilisation of knowledge are the main elements of the knowledge management process. Among them, knowledge transfer could achieve huge attention (Argote et al., 2000; Hasnain, 2016). King (2006) finds " knowledge transfer is the focused, objective seeking communication of knowledge between the individuals, groups, or organisations such that the recipient of knowledge (a) has cognitive understanding (b) has the ability to apply the knowledge, or (c) applies the knowledge" (p. 498). For smooth transfer of knowledge between the actors (sender and the recipient), selection and application of proper knowledge transfer mechanisms is paramount. Knowledge transfer mechanisms are the vehicles through which knowledge is transferred between the actors. In the military, the selection and utilisation of proper knowledge transfer mechanisms is absolutely crucial both during peace and war times. In appropriate selection and utilisation of knowledge transfer mechanisms may be dangerous for the military units and formations.

\section{FACE-TO-FACE MEETINGS AND DURBAR}

Military units and formations have their own techniques of transferring knowledge to the subordinates. Certain mechanisms are formal and certain mechanisms are informal in nature. Some formal and informal mechanisms of knowledge transfer are appended below.

\section{Face-to-Face Meetings}

Tacit knowledge is valuable. It is not found in the military journals, manuals, instructions or in military appreciations/operational plans. It is orally generated and shared around water cooler or over coffee break (Ngah \& Jusoff, 2009). Davenport \& Prusak (2000) and Jasimuddin's (2007) empirical findings on knowledge transfer mechanisms clearly report that face-to-face conversation is a commonly used mechanism of knowledge transfer. In the military, face-toface meeting may take in various manners. Brown bag lunches, when the unit members informally meet and talk on any official matter/procedure(s) in the unit tea/coffee bars during the lunch or coffee break times. Morning briefings may take place in the office of the unit Commanding Officer. In such meetings, generally, the officers talk on the progress of previous day's activities and also the next day's plan. These meetings last for a very short duration, say maximum 30-minuties. All ranks daily briefing/meeting, before the starting of the morning physical training period, may take place for a length of 10/15 minutes. Roll Calls, usually a parade where the attendance of the JCO (Junior Commissioned Officer), NGO (NonCommissioned Officer) and Private is counted after the last light, are used as a good vehicle for knowledge transfer by many military units/formations. A specialised person/officer may talk on any constructive subject/procedure in such parades.

\section{Durbar}

Durbar is one of the media of knowledge transfer. "Durbar" is originally a Persian word. Nowa-days, it is frequently used in Urdu, Hindi, Bengali and English literature. In the military unit level durbar is presided over by the Commanding Officer where all members of the unit remain present. Any JCO, NGO, or Private of the unit may put forward his/her point (s) before the Commanding Officer. Durbar is a routine monthly military activity in the units. The points are collected before the scheduled date of the durbar in the unit so that the Commanding Officer gets enough time to prepare the answers/decisions. However, impromptu points are also welcomed by the Commanding Officers in the durbar. Usually the officers do not put forward any point before the Commanding Officer in Durbar. The Commanding Officer may advise the members of the unit in the Durbar. British National Army Museum (2015) informs about the Colonel James Skinner's Regimental Durbar in 1827. Drawing the reference of a watercolour painting of Golam Ali Khan published in 1827, British National Army Museum (2015) continues by informing "Skinner... presiding over a durbar (council) of his regiment, an 
occasion when any soldier was at liberty to raise with his commanding officer anything that concerned him. The holding of a durbar, when Skinner mixed freely with his soldiers and men, was a conscious re-creation of Afghan and Mughal military and ceremonial traditions, which gave his soldiers a corporate sense of their 'upward mobility' in the Company's service".

\section{MILITARY EXERCISES, MODEL DISCUSSIONS, EXERCISE DEBRIEFINGS AND DEMONSTRATIONS}

Military organisations organise various types of training events. These training events are the vehicles of knowledge transfer. These events may have different objectives. Such mechanisms help the military units and formations enrich knowledge.

\section{Military Exercises and Training}

Military exercises are the well-known and interesting training events in the defence services. Many countries organise military exercises jointly with their friendly countries. Joint military exercises may have political causes. For example, "Estonia stages biggest military exercise [mobilised 13,000 soldiers] in country's history amid fears of Russian 'aggression'. NATO tries to reassure one of its most exposed members by sending 1,000 troops from US, UK [and] to the war games" (Farmer, Lasna \& Blair, 2015, p.1). However, joint military exercises, do not keep them confined only within the political orbit, they are also the excellent mechanisms for knowledge transfer between the knowledge haves and the knowledge have-nots, and thus help the militarily weak countries develop their military efficiencies. Training members of the recipient organisation, planned social activities, providing documents, blueprints, or hardware that embody knowledge to the recipient organisations (Easterby-Smith, et al., 2008) are the easy and simple mechanisms of knowledge transfer in the military organisations. Every year US defence forces impart training to the military forces of friendly countries. Military exercises, as if representing the real battle situation, are the artificial war games between the friendly forces and the set enemy forces based on proper pre-planned tactical planning.

\section{Model Discussions}

Almost all the military forces in the world, model discussions are widely used both during peace and war times. The battle field exact landscape is constructed with terracotta/clay or other materials in miniature forms in a room/open space. Own and enemy battle field dispositions are shown with symbols in the miniature model. The battle situation and courses of action is analysed by the discussants.

\section{Military Exercises without Troops}

Military exercises without troops are the mechanisms of knowledge transfer between the leaders. The military leaders, mainly the officers, participate in this exercise and no JCO/NCO or soldier is allowed to attend the same unless it is essential. The imaginary battle scenario/situation is created on papers keeping a particular landscape in mind. The participants can see the location on the military maps and they need to study those before attending the discussion physically at that particular location. On the scheduled date the leaders (officers) are divided into small groups (called syndicates) in the location where the exercise is carried out. Each syndicate is headed by a moderator/syndicate leader, who possesses huge knowledge on military tactics and strategy. Every member (officer) needs to provide their views and opinions on the subject under discussion. All ideas are welcomed by the moderator/syndicate leader. No idea/opinion is criticised. Each idea is carefully discussed and analysed. Finally, based on the discussion, the syndicate comes to a conclusion. 


\section{Military Logistics Exercises}

Military logistics units, the lifeblood for the fighting elements, carry out logistics exercises with a view to ensuring undisrupted supply chain in the battle/war situation. Exercises, both fighting forces and logistics, may work as mechanisms of knowledge transfer for each other.

\section{Exercise Debriefings}

Military exercises conclude with the debriefing sessions. These are high-quality knowledge transfer vehicles. Bartone and Adler (1995) clarify, "the Event-Oriented after Action Debriefing is a factual review of events, and individual and unit reactions to those events. It is an opportunity to sit down with fellow soldiers, reconsider what occurred, and draw lessons for the future" (p. 2). Further, they continue by analytically explaining it as a knowledge transfer media "in the process of reviewing events, feelings may be expressed and problems may be defused. The main point of the Debriefing is to review the chronology of events, to give soldiers an opportunity to clear up any confusion, and to facilitate a healthy cognitive reframing and integration of their experiences" (p. 2) .

\section{Demonstrations}

In military, demonstrations are frequently arranged for all ranks. Demonstrations give the opportunities to see how the operations are carried out and the military personnel may have the clear idea on the individual roles during the war time. In addition to operational demonstrations like, attacks, raids, ambushes, anti-terrorism operations, units and formations also arrange administrative demonstration like, fire fighting, fire alarms etc. Drama may be compared with demonstration. Drama is used as a knowledge transfer vehicle to exhibit the social folios. This mechanism of transferring knowledge is not new (Garaventa, 1998). From ancient Greek and Roman philosophers to contemporary play wrights dramas have been used as the way to mirror and explore the human condition (George, et al., 1998). Further, George et al. (1998) classify drama based training into low-impact training (e.g., focus on the topic for a wide audience that is not much familiar with the subject), moderate-impact training (audience members are more involved and they are invited to ask question to the actors after the performance) and in high-impact training is staged by the trainees and it is contextual (flight simulator where the trainee is the actor). Low impact training may be compared with the demonstrations in military. All exercises without troops are nearer to medium impact, while exercises with troops followed by debriefings may be treated as high-impact training.

\section{CONCLUSION AND FUTURE RESEARCH}

The functions of the military organisations are strategically and operationally different than those of the business organisations. Here the game is not with the profit and losses rather it is a game of live and death. The military units use numerous mechanisms of knowledge transfer. These mechanisms are the vehicles through which knowledge is transferred between the units/formations. A good knowledge transfer mechanism would ensure a smooth transfer of knowledge both in peace and war times, while a faulty mechanism is suicidal during the time of crisis. Face-to-face mechanism of knowledge transfer is one of the vital mechanisms of knowledge transfer where the chances of misunderstanding between the commanders and the Privates are less. Durbar can be an excellent tool of knowledge transfer and also morale boosting event for a unit/formation. Military training exercises are the training events and mechanisms of knowledge transfer where all ranks, units and formations have the opportunity of knowledge transfer. Model discussions help to plan early for any forthcoming or imaginary battle situation. Exercise debriefings are the mechanisms where the participating members have the opportunity to learn out of the mistakes and avoid such mistake in the real war 
situations. Demonstrations may be compared with dramas where the battle-field mistakes may be exhibited before the unit/formation members.

Future researchers may empirically investigate the issues in the context of any military setting.

\section{References}

Alavi, M. \& Leidner, D. E. (2001). Knowledge management and knowledge management systems: Conceptual foundations and research issues, MIS Quarterly, 25 (1), 107- 136

Al-Asmari, A.A. (2013). 'Origins of an Arab and islamic intelligence culture', Davies, P. H.J. \& Gustafson, and K.C. (ed.) Intelligence Elsewhere: Spies and Espionage outside the Anglosphere. Washington DC: Georgetown University Press, pp. 89-114.

Albino, V., Garavelli, A. C. \& Gorgoglione, M. (2004). Organization and technology in knowledge transfer. Benchmarking: An International Journal, 11(6), 584-600.

Albino, V., Claudio, G.A.\& Schiuma, G.(1999).Knowledge transfer and inter-firm relationships in industrial districts: The role of the leader firm. Technovation, 19, 53-63.

Alex, B., David, B. \& Lee, S. L. (2010). Exploring the military contribution to KBD through leadership and values, Journal of Knowledge Management, (14) 2, 314 - 330.

Argote, L. (1999). Organizational Learning: Creating, Retaining and Transferring Knowledge. Massachusetts: Kluwer Academic Publishers.

Appleyard, M.M. (1996). How does Knowledge flow? Interfirm patterns in the semiconductor industry. Strategic Management Journal, 17 (Winter Special), 137-154.

Argote, L. \& Ingram, P. (2000). Knowledge transfer: A basis for competitive advantage in Firms. Organisational Behaviour and Human Decision Procesess, 82 (1), 150-169.

Argote, L., Ingram, P., Levine, J.M. \& Moreland, R.L. (2000). Knowledge transfer in organizationns: Learning from the experience of others. Organisational Behaviour and Human Decision Processes, 82 (1), 1-8.

Argote, L., McEvily, B. \& Reagans, R. (2003). Managing knowledge in organizations: An integrative framework and review of emerging themes. Management Science, 49(4) 571-582.

Bartone, P.T. \& Adler, A.B. (1995). Event-Oriented Debriefing Following Military Operations: What Every Leader Should Know. Washington: US Army Medical Research Unit-Europe Unit 29218.

Bell, D.G., Giordano, R. \& Putz, P. (2002). Inter-firm sharing of process knowledge: Exploring knowledge markets. Knowledge and Process Management, 9(1), 12-22.

British Army (2015).The Intelligence Corps. Available:http://www.army.mod.uk/intelligence [Accessed: 8th June 2015].

British National Army Museum (2015). Colonel James Skinner holding a Regimental Durbar, 1827. Available at: http://www.nam.ac.uk/onlinecollection/detail.php?acc=1956-02-27-3 [Accessed: 17 May 2015]

Butler-Bowdon, T. (2010). Sun Tzu- The Art of War: The Ancient Classic .West Sussex: Capstone Publishing.

Chae, B. \& Bloodgood, J. M. (2006). The paradoxes of knowledge management: An eastern philosophical perspective. Information and Organization, 16(1), 1-26.

Chowdhury, D. (2009). The Determinants of Knowledge Transfer in Turkish Textile and Apparel Industry. PhD Thesis. University of Plymouth (unpublished).

Connell, N.A.D., Klein, J.H. \& Powell, P.L. (2003). Its tacit knowledge but not as we know it: Redirecting the search for knowledge. Journal of the Operational Research Society, 54 (2), 140-152.

Debowski, S. (2006). Knowledge Management. Sydney: John Wiley \& Sons Australia Ltd.

Darr, E.D., Argote, L. \& Epple, D. (1995) the acquisition, transfer and deprecation of knowledge in service organisations: Productivity in franchises. Management Science, 41 (11), 1750-1762. 
Darr, E.D. and Kurtzberg, T.R. (2000) an inVaustigation of partner similarity dimensions of knowledge transfer. Organisational Behaviour and Human Decision Processes, 82(1), 28-44.

Davenport, T.H. \& Prusak, L. (1998). Working Knowledge: How Organizations Manage What They Know. MA: Harvard Business School Press

Davenport, T.H. \& Prusak, L. (1998). Working Knowledge: How Organizations Manage What They Know. MA: Harvard Business School Press.

Dimovski, V, Marič, M., Uhan, M., Đurica, N. \& Ferjan, M. (2012). Sun Tzu's "The Art of War"and implications for leadership: Theoretical discussion. Organizacija, 45 (4), 151-158.

Dyer, J. H. \& Nobeoka, K. (2000). Creating and managing a high performance knowledge sharing network: The Toyota case. Strategic Management Journal, 21 (3), 345-367.

Easterby-Smith, M., Lyles, M.A. \& Tsang, E. W.K. (2008). Inter-organizational knowledge transfer: Current themes and future prospects. Journal of Management Studies, 45(4), 677-690.

Edvardsson, I.R. (2006). Knowledge management and SMEs: the case of Icelandic firms. Knowledge Management Research \& Practice, 4 (4), 275-82.

Farmer, B., Lasna \& Blair, D. (2015). 'Estonia stages biggest military exercise in countries history amid fears of Russian 'aggression". The Telegraph, 12th May.

Fireston, J.M. \& McElroy, M.W. (2005). Defining knowledge management: Knowledge Management or not knowledge management? That is the question, Strategic Direction, 21 (10), 22-24.

Garaventa, E. (1998). Drama: A tool for teaching business ethics. Business Ethics Quarterly, 8(3), 535-545.

George, J. S., Schwager, S. \& Canavan (1998). A guide to drama-based training. Employment Relations Today, 25(4), 15-19.

Gettier, E. L. (1963). Is justified true belief knowledge? Analysis, 23 (6: Jun), 121-123.

Goh, C. \& Hooper, C. (2009).Knowledge and information sharing in a close information environment. Journal of Knowledge Management, 13(2). 21-34.

Grant, R.M. (1996). Toward a knowledge-based theory of the firm. Strategic Management Journal, 17 (Winter Special Issue), 109-112.

Grant, R. M. (1997). The knowledge-based view of the firm: Implications for management practice. Long Range Planning, 30(3), 450-454.

Hall, B.P. (2001) Values development and learning organisations of Knowledge. Journal of Management, (5) 1, 1932.

Hasnain, S. S. (2016). Knowledge Management in Non-Governmental Organisations: Towards a New Horizon. New York (USA): International Institute for Science Technology \& Education.

Hasnain, S.S., Jasimuddin, S. M. and Fuller-Love, N. (2016). Exploring Causes, Taxonomies, Mechanisms and Barriers Influencing Knowledge Transfer: Empirical Studies in NGOs. Information Resources Management Journal, 29 (1), 39-56.

Hasnain, S.S. \& Jasimuddin, S. M. (2012). The Barriers to Knowledge Transfer: An Empirical Study in the NonGovernmental Organisations (NGOs) in Bangladesh. World Journal of Social Science, March 2 (2), 135-15.

Hensen, M. T., Nohria, N., \& Tierney, T. (1999). What's your strategy for managing knowledge? Harvard Business Review, 77 (2), 106-116.

Hippner, C. (2009). A Study into the Size of World's Intelligence Industry. Msc. Thesis (unpublished). . Faculty of Mercyhurst College. Erie, Pennsylvania.

Hislop, D. (2005). .Knowledge Management in Organizations-A Critical Introduction. NY: Oxford University Press.

Hogberg, C. \& Edvinsson, L. (1998). A design for futurizing knowledge networking. Journal of Knowledge

Management, 2 (2), 81-92. 
Howell, P. (2003). Indigenous early warning indicators of cyclones: Potential application in coastal Bangladesh. Diaaster Stydies Working Paper 6. Benfield Hazard Research Centre. Available at:

http://www.unisdr.org/files/1529_workingpaper6.pdf.

[Accessed: 19th October 2011].

Huber, G. (2001). Transfer of knowledge in knowledge management systems: Unexplored issues and suggested studies. European Journal of Information Systems, 10, 72-79.

Inkpen, A.C. (2008). Knowledge transfer and international joint ventures: The case of nummi and general motors. Strategic Management Journal, 29, 447-453.

Jasimuddin, S.M. (2007). Exploring knowledge transfer mechanisms: The case of a UK-based group within a hightech global corporation. International Journal of Information Management, 27, 294-300.

Keller, G. F. (2008). The influence of military strategies on business planning. International Journal of Business and Management, 3 (5), 129-134.

Mace, B. \& Thomason, G. (2008). Knowledge management is combat power. Marine Corps Gazette, 92 (6), 37.

Marquardt, M. J. (1996). Building the Learning Organization: A Systems Approach to Quantum Improvement and Global Success. NY: McGraw-Hill.

Mu, J., Peng, G. \& Love, E. (2008). Interfirm networks, social capital, and knowledge flow. Journal of Knowledge Management, 12(4), 86-100.

Ngah, R. \& Jusoff, K. (2009). Tacit knowledge sharing and SMEs' organizational performance. International Journal of Economics and Finance, 1 (1), 216-220.

Nonaka, I. \& Takeuchi, H. (1995). The Knowledge Creating Company. Oxford: Oxford University Press.

Pan, S. L. \& Scarbrough, H. (1998). A Socio-technical view of knowledge-sharing at Buckman Laboratories, Journal of Knowledge Management, 2 (1), 55-66.

Paul, B.K. (2009). Why relatively fewer people died? The case of Bangladesh's cyclone sidr. Nat Hazards, 50, 289304.

Penrose, E. (1959). The Theory of the Growth of the Firm. New York: Wiley.

Philip, W. R. \& Martin, C.P. (2009). A philosophical approach to time in military knowledge management. Journal of Knowledge Management, (13) 1, 171 - 183.

Richter, F. \& Vettel, K. (1995). Successful joint ventures in Japan: Transferring knowledge through organisational learning. Long Range Planning, 28 (3), 37-45.

Rowe, N.C. (2009). The ethics of cyber weapons in warfare. International Journal of Cyberethics, 1(1), 20-31.

Royal Corps of Signals (2015). Royal Corps of Signals. Available at: http://www.army.mod.uk/signals/signals.aspx [Access date: 30th May 2015).

Scarbrough, H. (1995). Blackboxes, hostages and prisoners, Organization Studies, 16 (6), 991-1019.

Scarbrough, H., Robertson, M. \& Swan, J. (2005). Professional media and management fasion: The case of knowledge management, Scandinavian Journal of Management, (21) 2, 197-208.

Singh, L. (1979). Indian Sword Strikes in East Pakistan. New Delhi: Vikas Publishing House.

Sun Tzu- The Art of War: The Ancient Classic (2010). West Sussex: Capstone Publishing.

Thompson, L., Gentner, D. \& Lowenstein, J. (2000). Avoiding missed opportunities in managerial life: Analogical training more powerful than individual case training. Organizational Behavior Human Decision Process, 82 (1), 60-75.

Van Wijk, R., Jansen, J.J.P. \& Lyles, M. A. (2008). Inter- and intra-organizational knowledge transfer: A metaanalytic review and assessment of its antecedents and consequences. Journal of Management Studies, 45(4), 830853. 
Hasnain, S. S. (2016). A Few Good Knowledge Transfer Mechanisms: Keys to Successful Miltiary Operatoins. Archives of Business Research, 3(4), 18.

Wathne, K., Roos, J. \& von Krogh, G. (1996) 'towards a theory of knowledge transfer in a cooperative context' in von Krogh, G. and Roos, J. (eds.) Managing Knowledge: Perspectives on Cooperation and Competition. London: SAGE Publications Ltd. pp. 55-81.

Wong, Y., Maher, T. \& Lee, G. (1998). The strategy of an ancient warrior: An inspiration for international managers. Multinational Business Review, 6(1), 83-93. 